\title{
COMPARATIVE EVALUATION OF. THE MANAGEMENT CONTRACT (MC) AND WORK CONTRACT (WC) SYSTEMS AND THE BENEFITS OF MANAGEMENT CONTRACTS IN JAPAN
}

\author{
Yasuaki KOBAYASHI
}

Member of JSCE, Professor, Department of Civil Engineering, Ashikaga Institute of Technology (Ashikaga 326, Japan)

\begin{abstract}
Now that Japan's period of rapid economic growth is over and markets are becoming more global, change is being forced on the systems by which the Japanese construction market operates and on construction companies themselves. In particular, many predict that project delivery systems will become more diverse as the construction market internationalizes. Taking the position that there are advantages to the Management Contract system - which is already well-established in the U.S. and advanced European countries - this paper compares this contracting system with the Work Contract system and identifies its possible benefits to Japan.
\end{abstract}

Key Words: construction project delivery system, management contract, construction management, construction market

\section{INTRODUCTION}

The Management Contract system was introduced as a variance of the construction project delivery system in a public project in the U.S. about 20 years $\mathrm{ago}^{1)}$. The construction project delivery system, a term not widely known in Japan and thus not often used, is defined as an organizational concept which assigns specific responsibilities and authorities to people and organization, and which defines relationships of the various elements in the construction of a project ${ }^{2)}$. It is a contractual system where a contractor is assigned by the owner to accomplish a construction project on a contract basis, implements the project and delivers it to the owner.

The Management Contract system is seen as an alternative of a work contract, a form of traditional construction project delivery system ${ }^{3), 4)}$.

Supplementation of performance and capabilities of an owner are the prerequisites of a Management Contractor, as already reported in various papers and books ${ }^{5), 6)}$.

These two factors are what characterizes a Management Contract System.

The General Service Administration of the U.S. Government, which was the first to institutionalize the Management Contract system, named the new system Construction Management. Since then, the term Construction Management has been generally used in the American construction industry. In this paper, the terms Management Contract (MC), Management Contract (MC) service, and Management Contractor ( $\mathrm{MCr}$ ) mean the same as Construction Management (CM) contract, Construction Management (CM), and Construction Manager (CMr), respectively.

\section{EVOLUTION OF CONSTRUCTION PROJECT DELIVERY SYSTEM}

In general terms, construction project delivery system historically has followed the evolution indicated in Fig. 1. These main stages in its evolution are (1) the force account or direct contract, (2) the own-design and construction contract, (3) separate contracts for design and construction, (4) the design and build contract, (5) the turnkey contract, and finally (6) the management contract.

This evolution is clearly defined in those countries where it is the local construction industry that leads the country's construction market. This includes the advanced countries of the West, Japan, and some Asian countries; that is, countries that have their own competent construction industry.

In the U.S., the construction industry has followed this evolution up to stage (6). In Japan, on the other hand, we have reached stage (3) in the realm of public works and stage (5) in private sectors. Thus the concept of Management Contracts is not yet utilized in Japan. The only experience Japanese construction companies have with Management Contracts is in work carried out in the U.S. and other countries, if any.

\section{(1) Force Account or Direct Contract}

In the direct method, the owner makes use of inhouse functions and capabilities to see construction projects to completion, as shown in Fig. 2.

\section{(2) Own-design and Construction Contract}

With this method, the owner makes use of inhouse engineers to develop the design. A construction company is then contracted to actually implement the project, as shown in Fig. 3. 


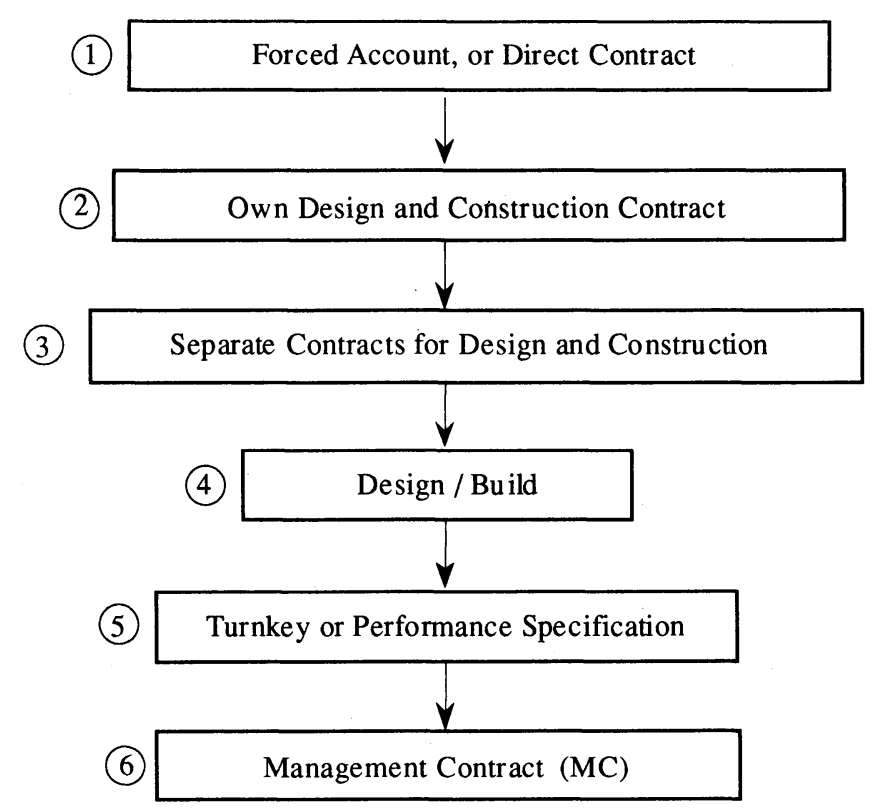

Fig. 1 Establishment of Construction Management Systems in Sequential Situation

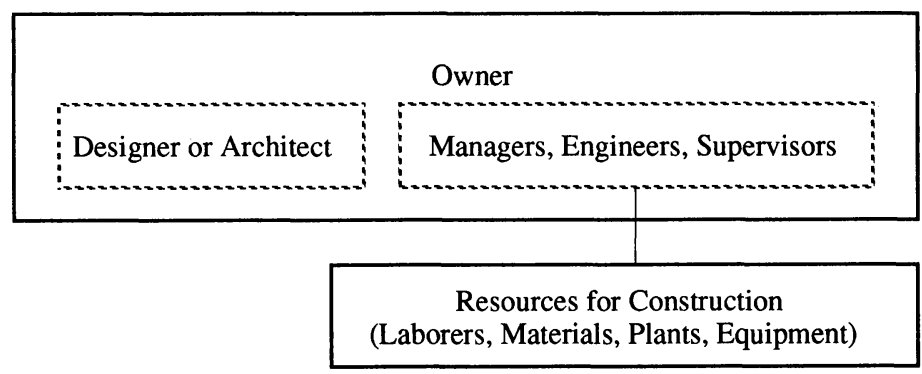

Fig. 2 Force Account or Direct Contract

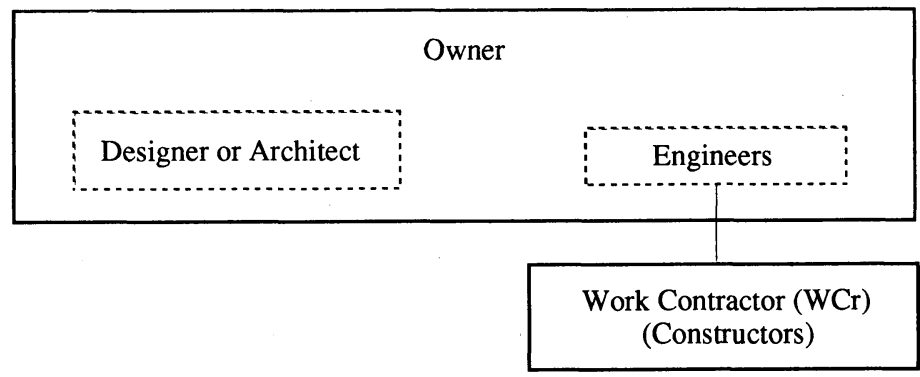

Fig. 3 Own-design and Construction Contract

\section{(3) Separate Contracts for Design and Construction}

In this method, as shown in Fig. 4, the owner implements neither the design nor the construction itself, but rather contracts separately with architects and construction companies for the work. This separates the responsibility for design from that for construction in seeing a project to completion.

\section{(4) Design and Build}

With this method, the owner enters into a contract with a single company for the design and construction work as one, and that one 


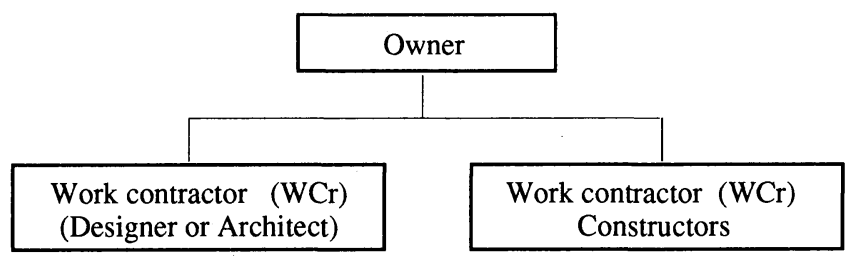

Fig. 4 Separate Contracts for Design and Construction

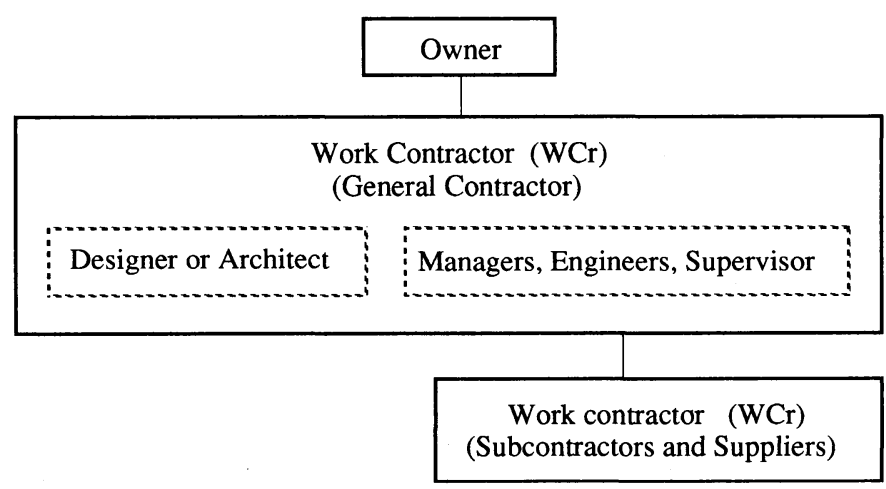

Fig. 5 Design and Build Contract (1)

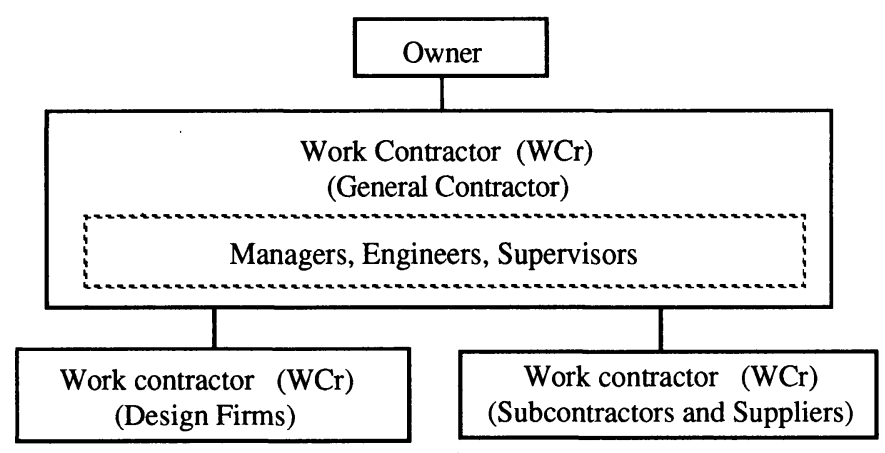

Fig. 6 Design and Build Contract (2)

company takes responsibility for both design and construction, as shown in Fig. 5 and Fig. 6.

\section{(5) Turnkey Contract or Performance Specification}

With this type of contract, the prime contractor - a general contractor - is responsible for both design and construction work. In this, it is somewhat similar to the design and build system. The main differences are that the scope of the contract and degree of responsibility are greater, more subcontractors are likely to be involved with the general contractor, and the system is more likely to be used for industrial plant construction projects than design-build.

\section{(6) Management Contract}

Under this contract method, a management contractor serves as proxy to the owner. This company manages all or part of quality, process, and cost control for whole or part of the planning, design, procurement, and construction of a project. Thus, the contractor acts as an aide in the implementation of the owner's project. There are basically two ways of implementing this type of contract, as shown in Fig. 7.

In Case 1 , the owner directly signs separate contracts with the design firm and constructor. This type of contract is often used for public works.

In Case 2, it is the management contractor that concludes contracts with architects or construction companies. This type of contract finds more favor in private projects.

In reality, many variations of the Management Contract system are in use, but all are modifications of these two cases. 

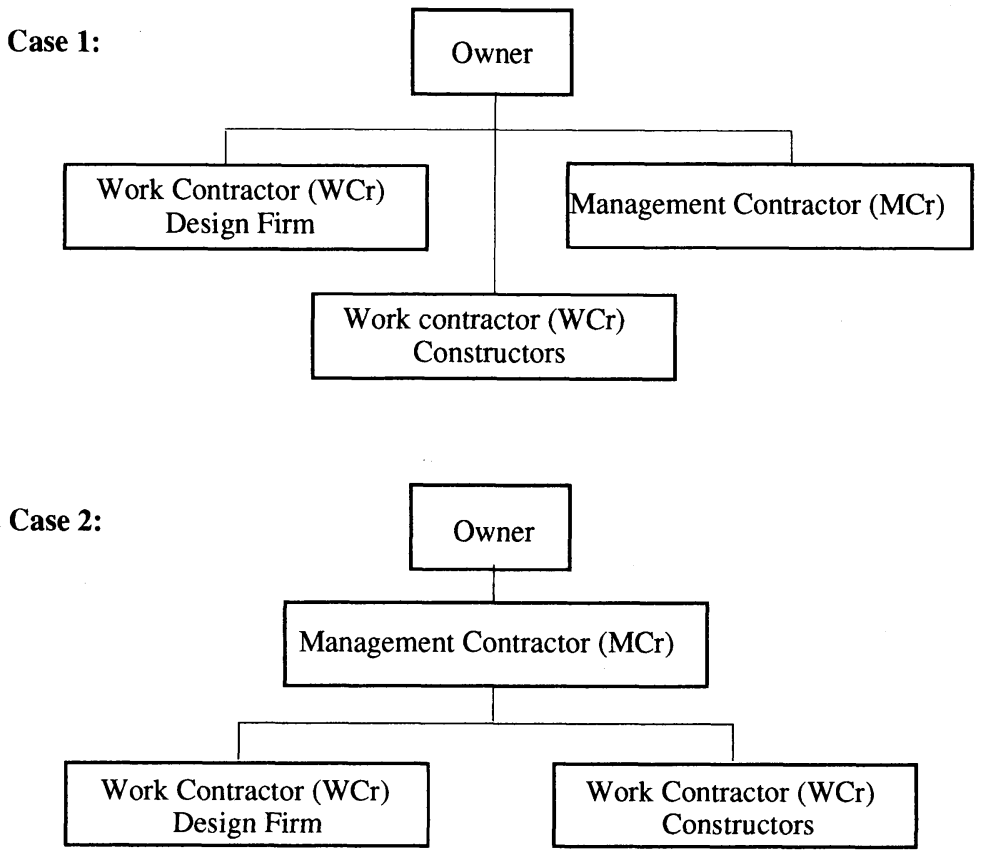

Fig. 7 Basic Management Contract System

Table 1 Fundamental Differences between Management Contract and Work Contract.

\begin{tabular}{|l|l|}
\hline Work Contract & $\begin{array}{l}\text { A contractor will: } \\
\text { - aim to secure its own profitability and reliability } \\
\text { - be entitled to specify the scope of work it implements } \\
\text { - implement the contracted work, including design or construction, and } \\
\text { complete the project } \\
\text { - be responsible for compliance with the specified cost, quality, and } \\
\text { construction period }\end{array}$ \\
\hline Management Contract & $\begin{array}{l}\text { A management contractor or construction manager will: } \\
\text { - not seek to profit of itself, but will aim to ensure profitability for the owner } \\
\text { by operating and managing the project as the owner's proxy } \\
\text { - cover all phases of the project life cycle; that is, carry out any type of } \\
\text { work required and asked for by the owner } \\
\text { not carry out any design or construction, nor be held responsible for its } \\
\text { completion, but will manage implementation of the work by contractors } \\
\text { approved or designated by the owner } \\
\text { - not be held responsible for compliance with the specified cost, quality, } \\
\text { and construction period (which are to be taken care of by the owner) and } \\
\text { will be held responsible only for management of the work }\end{array}$ \\
\hline
\end{tabular}

\section{DIFFERENCES BETWEEN MANAGEMENT CONTRACT AND WORK CONTRACT}

Table 1 lists the fundamental differences between the Management Contract and the Work Contract. These basic provisions may vary depending on the type of project, the conditions imposed by the owner, and the performance of the management contractor. An example of a modified version is the GMP (guaranteed maximum price) system where the management contractor is responsible for cost control. 


\section{REASONS FOR ADOPTING A MANAGEMENT CONTRACT AND THEIR SIGNIFICANCE}

The reasons companies choose to make use of the Management Contract in the U.S. are shown as follows.

- To compensate for qualitative and quantitative shortcomings among the owner's in-house engineering staff $^{7}$ )

Owners traditionally maintained enough inhouse engineers to implement their own projects, but recently the number of in-house staff has been falling as private companies come under pressure to cut costs and public organizations find that taxpayers are demanding smaller budgets. For organizations and companies which do not usually carry out construction projects, it is difficult to secure sufficient in-house personnel with the right skills when a project gets under way. Such problems in securing in-house staff are solved by the Management Contract method.

- To provide a range of contractors with the opportunity to participate in a project by offering separate contracts $\left.{ }^{8}\right)$

A small number of major general contractors continue to dominate the construction market, and small construction companies and specialty constructors find themselves under great pressure from this dominance, to the extent that their existence is threatened. Their pent-up feelings have surfaced as political pressure, and certain state governments have, as a consequence, enacted laws stipulating the use of separate contracts in public construction work. In the case of construction projects under separate contracts, an increase in the number of construction companies involved may lead to an increase in the complexity of management tasks to be performed by the owner and the number of inhouse staff he requires. Recently, in the U.S., public organizations have been criticized by the public for increasing the size of their in-house staffs. To enhance management capabilities without increasing in-house staff, it is effective for the owner to make the most of specialty management functions from the outside. The Management Contract system excels when project management is made complex by the participation of many companies, such as when separate contracts are offered in this way.

- To seek partners who side with the owner in project contracting and management ${ }^{9)}$

In the U.S., owners and contractors have equal powers and rights. An owner must be prepared to stand up to attack by the contractors, which may come in the form of contractual arguments, claims, and legal proceedings. Owners naturally feel it a great relief to have a company that always takes their side.
- To carry through management methods that are persuasive for the owner ${ }^{9}$ )

The Work Contract holds the contractor responsible for accepting the anticipated risks of a project. The contractor includes in the contract fee an amount to cover anticipated risk, so as to avoid an ultimate loss. If the actual losses attributable to risk do account for all the amount allocated, the anticipated cost of risk minus the actual losses is the contractor's profit. If actual expenditure as a result of risk exceeds the anticipated risk, the contractor suffers a loss. To offset this loss, the contractor usually serves a claim against the owner. If the claim is confirmed justified, the owner has to make up for the contractor's losses. Thus, according to the Work Contract, a contractor's profit remains the contractor's, while any loss often has to be compensated for by the owner. Owners are naturally unhappy with this system for its unfairness. The Management Contract is one way to eliminate such frustration.

With regard to significance:

- To avoid the major risks resulting from certain labor conditions 10$), 11), 12$ )

Where union power is strong, labor disputes including walkouts - often occur at construction sites. Construction companies then have to spend enormous amounts of time and money solving them, and may consequently fail to finish the work within the scheduled construction period. This results in expenditure exceeding estimates. For this reason, construction companies like to avoid contracted work. When construction companies are requested by the owner to implement construction work at a site under these circumstances, the companies can choose between the following two alternatives. One alternative is the Work Contract. Construction companies demand from the owner a sufficiently long construction period and, in order to ensure they do not lose money, an amount of money that includes the cost of all foreseeable risks. When the demands are not accepted by the owner, the companies making them do not enter into contract. If the owner decides to accept the Work Contract, it must be prepared to expend excessive amounts of money. The other alternative is the Management Contract. The Management Contract allows the owner, who is in a position under the Work Contract that labor issues are of little concern to him, to get involved in labor agreements as one of the interested parties. Construction companies that selected a position as a management contractor can steer clear of all sorts of labor issues. It becomes possible to unify policies on labor relations in a construction project by interesting the owner in labor issues. It is also possible to avoid mixed open-andclosed shops and union-and-non-union labor disputes due to the presence of multiple work contractors at a single construction site. Phased construction, one of the advantages of the Management Contract achieved by advancing 
construction work in subdivided phases, allows the owner to shorten the construction period and lessen the unforeseeable risks and disputes over labor agreements. The Management Contract method helps construction companies avoid the risk inherent in implementation of contracted work.

- To avoid the major risks caused by price escalation ${ }^{9)}$

Where unexpected escalation in commodity prices takes place after a construction contract has been signed, the contractor must spend more money than estimated and may suffer serious financial consequences. Construction companies quite often refuse to sign contracts and become reluctant to participate in bidding during a sharp acceleration in commodity prices. Under this economic climate, it is recommended that the owner adopt the Management Contract to implement a construction project. The Management Contract method helps contractors avoid such risks. Construction companies may have the will to conclude a contract with the owner if they take part in projects not as a work contractor but as a management contractor. The reason for this is that, since materials, equipment and labor are procured by the management contractor as required for the owner, payments needed for procurements are made by the owner, and the amounts paid by the owner are at current market prices, which convinces the owner that the management contractor can manage construction work free from the fear of damage arising from steep increases in commodity prices. As a result, since no hostility arises between the owner and management contractor, smooth implementation of construction work can be expected.

- Early commencement and completion of the work ${ }^{9)}$

Under the Management Contract method, a management contractor joins the project before the design and specifications are finalized, and may be able to begin construction earlier or advance its completion by taking measures such as fast tracking or phased construction.

\section{OPPORTUNITY FOR GROWTH OF MANAGEMENT CONTRACTOR CAPABILITY}

Even where there is demand for Management Contracts among owners, such owners will not be satisfied unless there are organizations and corporations in the marketplace capable of supplying appropriate Management Contract services. So let me now explain how such capabilities have developed in the U.S.

Private companies in the U.S. have developed the ability to serve as management contractors for historical reasons. The experience and character of the U.S. situation, as outlined below, have nurtured this ability.
- Prevalence of the Design and Build System

In the U.S., architects and engineers working in design or construction supervision are expected to work as proxy for the owner, and thus take up a position opposite that of the construction companies. In contracts related to governmental organizations and agencies, the separate design and construction contract method is still the norm.

As construction periods have been shortened in private contracts, major general contractors have introduced in-house design functions to cope with the demands placed on them by owners. This contributed to the adoption of the design and build system. One important index by which to assess the capabilities of a construction company is whether there is such an in-house design function or not.

- Development Based on the Developer Concept

A development project is a project undertaken by a company engaged in real estate development. The developer takes care of everything from development to financing based on company capital or funds raised from investors. Such developers have a range of inhouse functions, including real estate handling, financing, and general contractor services, and they regularly become involved in projects of this type. They have thus evolved management and coordination capabilities in areas such as construction planning, negotiation with architects, and management of subcontractors.

\section{- The Turnkey System}

The turnkey system resembles the design and build system, but is characterized by acceptance of a fixed sum to cover all costs, the provision of funds to cover all stages from design to construction, and the fact that ownership of the site is held by the construction company until completion of the project. This system grew out of the construction of facilities for major oil companies, and later spread to the construction of industrial plants such as power stations and chemical plants. General contractors with experience of turn-key contracts moved into general engineering construction, and they are generally strongly competitive and can bring the latest technology to bear.

\section{- Military Construction during World War II $\left.{ }^{13)}, 14\right), 15$ )}

During World War II, the U.S. government adopted an architect-engineering-management contract system. The Department of the Army needed to build military facilities with the utmost speed and there was no time for conventional procedures. The department chose a company capable of serving as a general contractor and entered into a contract. The general contractor then took care of everything -- including planning, drawing, and construction management -- as specified by the contract. The general 
Table 2 Review of U.S. Reasons for Introduction of Management Contracts and their Significance to Japanese Owners

\begin{tabular}{|l|l|}
\hline - To compensate for qualitative and quantitative shortcomings in the owner's in-house & Yes \\
engineering staff & Yes \\
- To provide a range of contractors with the opportunity to participate in a project by & offering separate contracts \\
- To seek partners who side with the owner in project contracting and management & No \\
- To carry through management methods that are persuasive for the owner & Yes \\
- Certain conditions exist or are expected to arise in the labor market that will cause \\
greater exposure to risk in contracting work \\
- Price escalation that will increase the risk of contracting work exists or is expected to \\
arise \\
- Early commencement and completion of the work & No \\
\hline & No \\
Additional considerations (peculiar to Japanese construction market) & Yes \\
* Means to effectively use human resources in the stagnant labor market & Yes \\
\hline
\end{tabular}

contractor did not itself carry out the work, but selected a number of subcontractors to handle specified tasks. The general contractor served as supervisor.

Experience with this type of contract during the war enabled such general contractors to become highly competitive after the war, and armed them with the very best of technology.

These four types of experience have enabled major general construction companies in America to accumulate great power and expertise, and such companies were able to develop into competent management contractors. When ability with Management Contracts became the main index by which to judge the viability of a constructor in the U.S. construction market, it is these general construction companies who came to dominate the marketplace.

It was the needs of owners that primed the market for the birth of Management Contract services, but it must be noted that it is the major general construction companies, not the owners, design firms, or consultants, that worked to expand the Management Contract market.

\section{UTILITY OF MANAGEMENT CONTRACTS IN THE JAPANESE CONSTRUCTION MARKET}

\section{(1) Utility}

Are the reasons for the popularity of the management contract system in America applicable also to Japan? This question is considered in Table 2, which looks again at the various points considered above.
- To compensate for qualitative and quantitative shortcomings in the owner's in-house engineering staff

In Japan, many organizations suffer from a lack of engineers, especially in local government and government agencies. Introduction of the Management Contract method might be useful as a solution.

- To provide a range of contractors with the opportunity to participate in a project by offering separate contracts

Take, for example, a construction project involving management contractors with good management skills (such as major general contractors). In such a project, demarcation of responsibilities and identification of responsibilities assigned to both major and smaller construction companies, or between general contractors and specialty contractors, would be encouraged. This might trigger a hierarchical shift in Japan's construction industry.

To seek partners who side with the owner in project contracting and management

In Japan, owners and contractors do not historically have an antagonistic relationship. Their relationship is based on long-term mutual trust. An owner therefore does not feel the need for support of the type offered by the Management Contract system.

- To carry through management methods that are persuasive for the owner

As things stand, the cost of a public construction project in Japan is estimated according to a standard system. This price is called the scheduled price. This means an owner knows exactly the cost of the work. Thus, the 
scheduled price is unviolable. No VE by third parties or contractors is permitted.

If the Management Contract system were introduced, it would clarify the otherwise unseen difference between owners' scheduled prices and the actual work costs by "opening the lid," thereby helping to clarify details of production costs and encouraging economic efficiency by allowing VE.

- Certain conditions exist or are expected to arise in the labor market that will cause greater exposure to risk in contracting work

Construction workers in Japan do not stage strikes nor become involved in labor disputes. Thus, there is no current labor problem that might be solved by the introduction of Management Contracts.

- Price escalation that will increase the risk of contracting work exists or is expected to arise

Commodity prices in Japan are stable, at least at present. No conceivable commodity price problem could be solved by the introduction of Management Contracts.

- Early Commencement and Completion of the Work

Methods which assist in speeding up a project, such as fast tracking or phased construction, are some of the standard procedures employed in general work contracts in Japan. The introduction of the Management Contract system therefore would have no effect of further shortening construction periods.

So, of the seven forces that led to popularity of the Management Contract system in America, three are certainly applicable in Japan. Additionally, there are two more reasons particularly applicable to the Japanese situation. They are:

- Means to Effectively Use Human Resources in the Immobile Labor Market

Both government organizations and private corporations in Japan operate a system of lifetime employment. This means the labor market tends to be immobile, and it is very difficult for governmental agencies and companies to employ the skilled and professional people whenever they need. It is also impossible to lay people off when a job is completed.

The concept of Management Contracts is quite useful as a means of flexibly utilizing the available skilled and professional human resources in a way that extends beyond organizational barriers such as closed employment structure.

- Market Price of Value-added Technology Supplied by Supporting Persons

Japan has enjoyed many years of rapid economic growth. The seniority system adopted by governmental agencies and major private companies delivers the goods only when the organization continues to expand as the economy grows. However, Japan's economy cannot be expected to grow as vigorously as in the past, and companies will have to restructure. White-collar workers will be required to become more productive, and head office employees will have to improve their cost consciousness. Companies will no longer be able to afford to provide value added technology including overhead.

- The introduction of Management Contracts would bring the market price concept to "valueadded" technology and help create new management principles to cope with the new economic era.

\section{(2) Capabilities of Japanese Management Contractors}

The Management Contract system has not yet been introduced into Japan's construction market, so private companies have no experience of this type of contract arrangement in a Japanese project. In order to judge whether private companies are capable of working to a Management Contract, let us look at whether the experiences of American construction companies are common also to Japanese companies.

- Prevalence of the Design and Build System

General construction companies in Japan have more mature design functions than their counterparts in the U.S., and have many years of experience with design assignments.

- Development based on the Developer Concept

The major Japanese general contractors made development projects one of their management strategies over 20 years ago, and now have a rich backing of experience in this area.

- The Turnkey System

The major Japanese general contractors made the development of new business one of their management strategies over 10 years ago, and have since been implementing all phases of projects, including planning, construction, and even financing.

- Military Construction during World War II

During the last war, Japanese construction companies were simply forced to supply labor for military work; they were deprived of freedom and independence in their operations.

In addition to these experiences which shaped the situation in the U.S., one additional experience is peculiar to the Japanese construction market.

- Support for Owners

It is standard practice for Japanese construction companies to offer technical assistance to owners. Through this experience, construction companies have accumulated 
Table 3 Usefulness of the Management Contract System for ODA Construction Projects in Less Developing Countries

\begin{tabular}{|l|l|l|}
\hline & \multicolumn{1}{|c|}{ Conventional method } & \multicolumn{1}{c|}{ Proposed method } \\
\hline Contract type & Work contract & Management contract \\
\hline Management type & Management by local owner & $\begin{array}{l}\text { Management by foreign } \\
\text { companies of developed } \\
\text { countries }\end{array}$ \\
\hline Work implementor & $\begin{array}{l}\text { Foreign companies of developed } \\
\text { countries }\end{array}$ & Local construction company \\
\hline $\begin{array}{l}\text { Role of local construction } \\
\text { company }\end{array}$ & $\begin{array}{l}\text { Subcontractor for foreign } \\
\text { companies or no chance of } \\
\text { participation }\end{array}$ & Potential prime contractors \\
\hline $\begin{array}{l}\text { Future of local construction } \\
\text { market }\end{array}$ & $\begin{array}{l}\text { Dominated by foreign } \\
\text { companies of developed } \\
\text { countries }\end{array}$ & Growth of local companies \\
\hline
\end{tabular}

knowledge of the upstream side of a project's life cycle.

This review indicates that Japanese major general contractors are fully capable of offering Management Contract services if the system were to be introduced.

\section{(3) Usefulness in Foreign Markets}

Japan carries out many Official Development Assistance (ODA) construction projects in various developing countries. It would be advantageous to introduce the Management Contract system in taking on these projects.

As indicated in Table $\mathbf{3}$, if Japanese construction companies or consultants were to become management contractors for ODA projects in the foreign countries, local owner organizations would be able to learn management technique while local construction companies would have a chance to learn on the jobs from the management contractors.

\section{CONCLUSION}

This paper has considered the possibility of introducing the Management Contract system into Japan and the advantages it offers. The analysis is backed up by the experience gained with the use of the Management Contract method in the U.S..

The Japanese construction industry and construction companies are now at a turning point. Particularly, since the construction practices have been maintained and used for so long, it is frequently pointed out that they need replacement, renovation, or restructuring. It is clearly time for new systems and methods to be adopted or developed. Introducing the Management Contract system today would be very effective and beneficial.
ACKNOWLEDGEMENT: My sincere appreciation to Professor $M$. Kunishima, University of Tokyo, and Director Gerald L. Rounds, Iowa State University, for their support in the preparation of this paper.

\section{REFERENCES}

1) ENR Editorial:World's tallest towers begin to show themselves on New York City Skyline Engineering News Records, Vol. 184, No. 1, Janualy 1, 1970.

2) Kettle, Kenath A.: Project delivery systems for construction projects, Journal of the Construction Divisions, Proceedings of the American Society of Civil Engineers, Vol. 102, No. C04, pp. 576, December, 1976.

3) The Committee on Construction Management of American Society of Civil Engineers: Qualification and selection of construction manager with suggested guidelines for selection process, Journals of the Construction Engineering and Management, Proceedings of American Society of Civil Engineers, Vol. 113, No. 1, pp. 51-89, March, 1987.

4) Agc \#550 Owner Guidelines for Selection of Construction Manager, The Associated General Contractors of America (AGC), 1982.

5) U.S. General Services Administration, Public Building Services (GSA, PBS): Construction Management Guide, GSA, PBS, 1993.

6) The American Institute of Architect (AIA): The Architect's Handbood of Professional Practice, pp. 1112, AIA, Washington, DC, 1992.

7) Wong, Alan K.: Program management; intent, tool, practice, Proceedings of the Specialty Conference on Engineering and Construction Projects, pp. 29-42, The Construction Division of the American Society of Civil Engineers, 1982.

8) Levy, Sidney M.: Project Management in Construction, Second Edition, pp. 17-19, McGrawHill, Inc., 1994.

9) Scott \& Showalter: The History of CM services, pp 51-61, ASCE National Convention Construction Management, 1986.

10) Barrie Dpnald S. and Paulson Jr Boyd C.: Professional Construction Management, pp. 11-12, McGraw-Hill Book Co., 1992. 
11) Christesen, R. J. and Tatum, C. B.: Labor relations considerations on PCM projects, Journal of the Construction Divisions, Proceedings of the ASCE, Vol. 106, No. co4, pp. 540-542, December, 1982.

12) Tatum, Clyde B.: Evaluating PCM firm potential and performance, Journal of the Construction Divisions, Proceedings of the ASCE, Vol. 105, No. co3, pp. 239 251, September, 1979.
13) U.S. Department of Transportation, Federal Highway Administration (DOT, FHA): America's highways 1776-1976, a history of the federal-aid program, Chapter 11, DOT, FHA, 1976.

14) Ingram, Robert L.: Bechtel story, pp. 13-14 Privately printed by Bectel Co., 1968.

15) McCartey, Laton: Friends in High Places, pp. 57-70, Ballantine Books, 1989.

(Received April 1, 1996)

\section{Management Contract (MC) とWork Contract (WC) の比較検証と 我が国における Management Contract (MC) の有用性}

過去100年にわたって，維持され運用されてきた日本の建設市場の制度や建設企業の体質は，高度経済 成長の終焉と国際経済活動のボーダレス時代を迎えて，急激な変化を迫られている．特に，建設市場の国 際化の趨勢は，建設生産システムの多様化を促す可能性が予測される。それ故に筆者は，欧米で新しい建 設生産システムの一形態として既に定着して実績を積んでいるManagement Contract (MC) を，日本の建設 市場に構築しようとする試みは，価值があると確信している．その試みを具体的に提言するために筆者は， Management Contract (MC) とWork Contract (WC)の比較と日本におけるManagement Contract (MC) の有用 性について検証した結果を以下に述べる。 